\title{
HISTORY OF THE LIBRARY
}

\author{
By William H. S. Demarest
}

As a graduate of Rutgers in the Class of 1883 , as president of the college for nearly twenty years, and as author of A History of Rutgers College, Dr. Demarest, more than any other person, is the embodiment of Rutgers bistory. He bas, moreover, always taken particular interest in developing the resources of the Library, which be bas seen grow from a few thousand volumes lodged in the end of the Kirkpatrick Cbapel to the present large collection wbich is overflowing the Voorbees Library Building. We are fortunate to bave from bim a bistory of the Rutgers Library.

$\mathrm{T}$ the anxious and difficult enterprise of founding Queens College and in the confusion of war time at once thereafter, we hear nothing of any library problem or library foundation. The charter of 1766 and that of 1770 in presenting a program for the proposed college take it quite for granted that the trustees and teachers and students will have at command books apt to the ordained education.

It may well be imagined that from the first functioning of the college in I77I there were some books in the college house at the northeast corner of French and King Streets, now Albany and Neilson-books of Tutor Frelinghuysen who lived there or near by, or of Tutor Taylor soon with him and after him, or of President-pro-tem Hardenbergh who must have been constantly in and out, or perhaps books given by Domine Leydt of the old Dutch church and other domines and laymen responsible for the college start. It may well be concluded, however, that any such body of books there may have been was small indeed. Such must have been the fact still when the college moved in 1789 to its new College Hall where the Soldiers' Monument now stands at the foot of Livingston Avenue.

It is interesting that the first formal word as to books for a college library is of a gift or bequest by a graduate of the college, a young man, the Reverend Peter Leydt, brother of Matthew Leydt, the first graduate of Queens, I774, and son of the Reverend John Leydt, who had been so active and 
effectual in work for the infant institution. At the meeting of the Trustees April 10, 1792, a letter from John Haring, Esq., was read, telling of this donation; and James Schureman, Trustee, reports that the books have been received.

Through the succeeding years of the feeble and interrupted life of the college it was natural that there should be little evidence of library effort or advance. Then in 1807 at the making of the Covenant between the Trustees of Queens and the General Synod of the Dutch Reformed Church for its Theological Seminary, the library interest comes to the fore; and thereafter it is often in evidence though not for a long time at all largely advanced. The Theological Seminary was to remove from New York to New Brunswick; it did so in 1810 . The Trustees of the College at the same time built the building now known as Old Queens. The Seminary would naturally foster a collection of books appropriate to it; they would be joined with the books of the College. A committee of the College Trustees, reporting in $I_{18} I_{4}$ as to the Queens Building, added: "A considerable college library has also been procured which in a few weeks will be greatly increased," an optimism perhaps hardly justified. A librarian, however, was appointed at this time-who it was is not clear; and an appropriation was made for the purchase of books-\$100!

In the new building when finished there was now at least a library room. It was the room now used as the President's and Trustees' Room. The great shelves with glass doors from floor to ceiling, built at the time or very soon, no doubt, remained in the room until quite recent years, long after the books had been removed to a new home and the room become the classroom of history and political science. The library arrangements at the start were most modest. In I 825 when President Milledoler came and Queens College became Rutgers College, a student librarian was appointed and the opening time was fixed as 8:30 to 9:00 o'clock on Saturday mornings. The few students would be able in that time to draw what books they might want from the few at command; to read in the library apparently was not good form. 
In the early 'thirties there are two notable aspects of the library situation. One is a substantial accession of books from several sources: a gift of books from the library of Dr. John Clark, and from Mr. James Bogert, Jr., of New York, and, for theological books, money from Dr. Richie of Scotland; and the purchase of the library of Professor John De Witt after his death in 183I. His books were appraised at $\$ 2,104.59$, exclusive of 200 Dutch books. For their value to the Library and in kindness to Mrs. De Witt they were bought, the money being given by friends in the church connection. Then his successor, Professor McClelland, gave particular attention to the Library. In 1836 the Trustees voted him their thanks for his work in putting the books in order and fixing some better system of administration. However, whatever attention the Library received or whatever gifts or purchases were made, in I845 the number of books is reported as only 5,000 .

The other matter of special library interest at this period is the forming of the libraries of the Philoclean and Peithessophian Societies. These societies had been founded by the students, under impulse and encouragement by professors, at once on the revival of the college as Rutgers, I825, to continue their great program of literary and rhetorical exercise for the undergraduates until nearly the end of the century. A part of the functioning of each society was the composing of a library. From one source and another, by gift or purchase, the collections quickly became of substantial size and value. The books were chiefly standard literature and history, the College-Seminary library being no doubt chiefly theological. The societies had the rooms, first floor Van Nest Hall, Philo on the left, Peitho on the right. In general the rooms were opened for a brief time Saturday mornings for the drawing of books. No doubt these libraries served the students more than the main library. When, most unhappily, these societies became inactive near the end of the century, their books were merged into the College Library, which by that time had become of so much the greater service.

An incident of some moment in the story of the Rutgers College Library was of I856-1857. At that time a gradual 
process of separation of the College and the Seminary was coming to completeness, a dissolving of the Covenants of the early years of the century. The Seminary now acquired its own campus, just north of the College, and built its own building, Hertzog Hall, standing, in the words of that day, "in the midst of desolateness"- strange contrast to the campus beauty of today. This building had its library room, the large room on the second floor now used as the chapel. The books in the Queens Building were then divided, those belonging to the Seminary or especially appropriate to it being transferred to Hertzog Hall to remain there with later additions for eighteen years until I 875 when the fine Sage Library Building was completed, into which have been gathered in the years since, the large, valuable, and diversified collections which make it a library surpassed by very few among the theological seminaries of the United States.

The College Library thus reduced remained in Queens Building only a few years more. In I87I-I 872 its time of opening was from 3:00 to 4:30 o'clock on Friday afternoons. Professor Atherton was then the Librarian and Professor Hasbrouck, the Assistant Librarian. Now the Library was to have a new and more spacious home. In I 872 a residuary bequest of Mrs. Sophia Astley Kirkpatrick became available. The Trustees used it for the erection of the Chapel, which had been thought of as the first need of the College. The building, which would, however, house also the library, was designed by Mr. Henry Janeway Hardenbergh. On December 3,1873 , it was dedicated. The chapel room extended from the front entrance to where the larger pillars now stand. From that point to the rear entrance there were two floors, and the upper floor with its gallery was the library room. The books were removed to the new room, the new building. President Campbell was to raise $\$ 3,000$ for the purchase of reference books. But still after I880, the books were reported as only 10,000 in all.

In I 880 Professor Hasbrouck succeeded Professor Atherton as Librarian, to serve until I884. In that year Irving S. Upson became Librarian, a graduate of the Class of I88I, soon to become Registrar of the College, later to become 


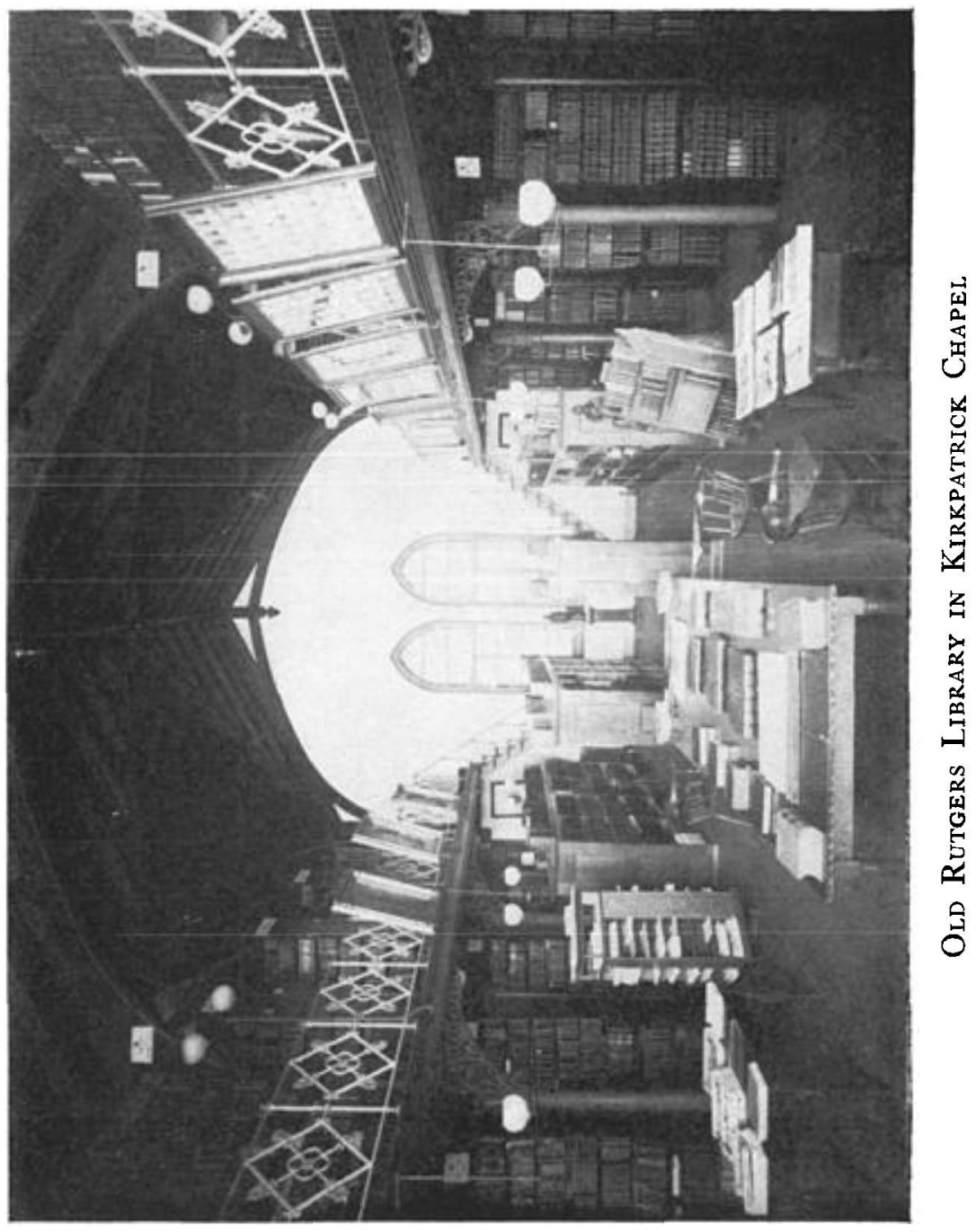


Treasurer also, but to remain Librarian for over twenty years, until 1905, and in his other offices until his death in his chair at his desk in I9I5. His record as a devoted and effectual officer of the College remains distinguished in the annals of Rutgers. He loved books, and he loved system. He would have preferred library work as his life vocation. Early in his time, I887, came the large and valuable gift of the $P$. Vanderbilt Spader library, especially rich in historical and literary values. By I 890 there were 26,000 books.

Through the succeeding years growth was constant and more rapid. From special sources books in the field of science were more largely added. George A. Osborn became a student assistant. At his graduation in I897 he came to catalogue rank as Assistant in the Library. It had become a large and constantly working institution, its values available to students at virtually all times. The growing body of books was becoming too great for the space provided for it. By 1903 there were about 45,000 volumes, crowded on the shelves, many hid behind others, and piled on the floor.

Then came a real library building. Mr. and Mrs. Ralph Voorhees of Clinton, New Jersey, gave $\$ 60,000$ for its erection, and it was dedicated, The Ralph Voorhees Library, in November 1903. It was located on the then extending campus, land given by Mr. James Neilson. Its architect was Mr. Henry Rutgers Marshall. At the dedication Mr. Voorhees was present; he was totally blind; he spoke to the throng gathered in the building his words of presentation, without sight at all of the people to whom he spoke or of the building which he gave. Into this new home of their own the books were removed and a new and very progressive era in library assets and service commenced.

As the Library now began its new era, faced its new opportunities and demands, and as all official programs of the College became more exacting, Mr. Upson retired from his office of Librarian. Mr. George A. Osborn, who had for some time been quite fully in charge, succeeded him with title of Acting Librarian, 1906-1907, and with full title of Librarian from 1907. It would be a most agreeable task to trace the accessions and the growth of service from that time 
did space and propriety permit, to tell the names of those whose valuable libraries have been given or who have given money for valuable additions or have established permanent funds for annual purchases; to tell all the sources especially of works of science. It would be a gracious task were it possible to recite the names of all those assistants who through the thirty years, and in earlier times, have carried on the busy service of the Library. Suffice it to say that in less than ten years there were 85,000 books and in about fifteen years 120,000 .

Then, the shelves again overcrowded and the service impeded, the building had become far too small. Again Mrs. Voorhees met the emergency giving $\$ 150,000$ in 1923 for the enlargement of the building into the more imposing and impressive form of the present day, the work done under initial advice of Professor Clarence Ward of the College and under the plan and direction of the architect, Mr. Edward L. Tilton. Again a new era of growth in values and in breadth of work, more rapid increase of books, more developed staff of workers, more wide reach of service.

Today, 1937, there are in the Library nearly 300,000 volumes and there are every day nearly I,200 calls at the Library by students, professors, and readers beyond the academic bounds. Again the shelves are overcrowded, the staff is inadequate, the service impeded. The embarrassment is a great tribute to the devotion and ability of the Librarian, to his zeal for adequate resources in each department, his flair for source material, especially historical documents, his ideal of immediate and adequate attention to every call.

A new library building-allowing surrender of present building to other urgent university need-is now essential, a building adequate for the present day and for some years to come and appropriate to addition at later time when new demands require it. It would be a singularly happy thing if assurance of it could come just now, the fortieth anniversary of the present Librarian's first formal appointment to the Library staff, the thirtieth anniversary of his appointment as Librarian. 